\title{
Thermodynamic and Theoretical Studies of average Ionization Constants of a Number of Phenolic Schiff Bases Derived from Salicylaldehyde by Conductivity Measurements
}

\author{
"Emad A.S. AL-Hyali ${ }^{*}$ FedaH.M.Al - Taai ${ }^{* *}$ Shatha S. Othman \\ ${ }^{*}$ Chem. Dept, College of Education, University of Mosul \\ ** Medical Instrumentation Engineering Dept,Technical \\ College/Mosul
}

تضمن هذا البحث تحضير ثلاث قواعد شيف تحمل في تركيبها مجاميع فينولية حامضية ومشتقة من تفاعل السلسلديهايد مع الاورثو والميتا والبارا امينوفينول ثم دراسة عدد من صفاتها الفيزيائية والتركيبة بواسطة أطياف الـ UV و IR فضلاً عن درجات انصهارها ـ قد تم حساب ثوابت تأين قواعد شيف المحضرة عند درجات حرارية مختلفة بواسطة طريقة قياسات التوصيلية ـ ثم درس تأثير تغير موقع مجموعة الـ OH بالنسبة لمجموعة الايمين على قيم ثابت التأين. كما تم حساب قيم الدوال الثرموداينمكية للتأين بالاعتماد على نتائج دراسة تأثير درجة الحرارة على قيم ثابت التأين. وقد تضمن البحث أيضاً حساب عدد من المتغيرات النظرية باستخدام أحد طرق ميكانيك الكم الشبه تجريبية المعروفة بطريقة اوستن . واشتملت هذه المتغيرات على (AM1)

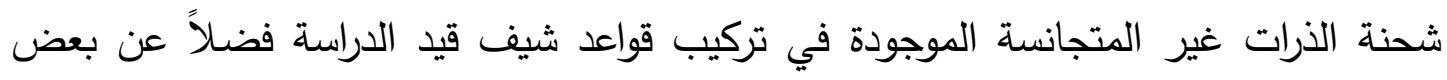
المتغيرات التركيبية والطاقية. وقد درست علاقة هذه المتغيرات بنمط تغير قيم ثوابت التأين للايمينات المحضرة. وقد قدمت النتائج النظرية المحصل عليها توضيحاً ودعماً للنتائج العملية, وبصورة عامة أظهرت محصلة نتائج هذه الدراسة تأثر قيم ثابت التأين بعامل الحث والريزونانس والإعاقة الفراغية فضلاً عن التآصر الهيدروجيني، وقد أثبتت الدراسة أن طريقة التوصيل الكهربائي هي طريقة سهلة ودقيقة يمكن استخدامها في حساب قيم ثوابت التأين 


\section{Abstract}

In this work, three Schiff bases carrying acidic phenolic groups were synthesized derived from the reaction of salicylaldehyde with $\mathrm{o}, \mathrm{m}$, and $\mathrm{p}$ amino phenols. A number of their physical and structural properties were determined by IR, UV spectra and melting points. The ionization constants of the synthesized Schiff bases were calculated at different temperatures by conductivity measurements. The effect of varying position of $\mathrm{OH}$ group with respect to the imine group on ionization constant was investigated. Depending on the results of varying temperatures, the thermodynamic functions of ionization were estimated.

The study also concerned with the calculation of a number of theoretical parameters by employing the semiempirrcal Austin method 1 (AM1) including the atomic charges present on the hetro atoms in the molecules, in addition to some energetical and structural parameters. The determined parameters were correlated to the variation of ionization constants of the synthesized imines. Explanation and support for the experimental results were provides by these calculations. The overall results proved that, the ionization constant is affected by inductive, resonance, steric and by hydrogen bonding, and can be determined simply, precisely and accurately by conductivity measurements .

\section{Introduction}

One of the most important problems of present day chemistry is the synthesis of a new substances and materials possessing a series valuable properties. Practically great prospects have been opened up in the synthesis and study of organic compounds having delocalized electrons because of the presence of conjugated bonds in the system. Schiff bases are compounds containing a carbon- nitrogen bond with nitrogen atom being connected to an aryl or alkyl group. The general formula of Schiff base is $\quad \mathrm{R} \mathrm{C}^{-} \mathrm{N} \mathrm{R}^{-}$, where $\mathrm{R}^{-}$and $\mathrm{R}^{-}$are alkyl or aryl groups, those make the Schiff base a stable imine ${ }^{(\mathbf{1})}$. Schiff bases have variety of applications in biological, clinical, analytical and pharmacological area ${ }^{(2)}$ - A great deal of attention had been given to the chemistry of imines for the last three decades using various techniques such as UV, IR, NMR and Mass spectrometry ${ }^{(3-4)}$. Electrical conductivity is proved to be rapid and accurate method for the determination of ionization constants of organic acids and bases ${ }^{(\mathbf{5})}$.In general, the values of ionization constants as observed by conductivity measurements are found to be affected by the chemical structure of the acid or base containing phenolic and other group as main factor, in addition to, steric effect and the formation of inter and / or intra molecular hydrogen bonds ${ }^{(6)}$. 
There are various methods that can be employed for the determination of ionization constants which lead in the end for the calculation of $\mathrm{pKa}$ values of the weak acids and bases. Electrical conductivity is proved to be rapid and accurate method for the determination of ionization constants of orange compounds ${ }^{(3-6)}$. In recent years, the values of pKa have been proven to be of great importance specially after the confirmation of its relation to various pharmacological properties such as analgesic activity and CNS depressant properties which were determined by potentiometric method for compounds like imidazole derivatives and Schiff bases ${ }^{(7-8)}$.

\section{Experimental}

\section{Materials :}

All the chemicals used in this study were supplied by the chemical companies Fluke, BDH and Molecula, and they were used without further purification.

\section{Synthesis of the Schiff bases:}

Three Schiff bases are employed in this investigation. They were synthesized by standard method ${ }^{(9)}$ by mixing equimolar amounts of o,m, and p-amino phenol with hydroxybenzaldehyde as in the general equation shown below :

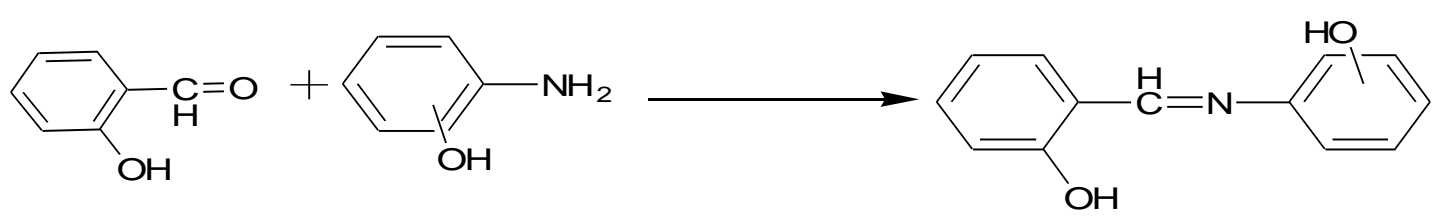

$10 \mathrm{ml}$ of ethanol is added to the mixture in order to facilitate dissolving the materials. The mixture was refluxed for 2 hours. The resulted solid was separated, washed, recrystalized with ethanol and dried. 
Thermodynamic and Theoretical Studies of average Ionization Constants ...

Table (1) : Names structures and melting points of the synthesized Schiff bases .

\begin{tabular}{|l|l|l|}
\hline Compound & Same & S. $\mathrm{P}^{\circ} \mathrm{C}$ \\
\hline
\end{tabular}

\section{Conductivity measurements:}

Electrical conductivity measurements are employed for the calculation of the values of $\mathrm{Ka}$ of the Schiff bases considered in this study. The measurements are carried out in the range of temperatures $\left(20-60^{\circ} \mathrm{C}\right)$. The following equations are used for achieving these calculations. Since the compounds considered are possessing two acidic protons, the average ionization process can be presented as follow:

$\mathrm{H}_{2} \mathrm{~A} \rightleftharpoons 2+\mathrm{A}^{\mathrm{E}}$

$C(1-\alpha) \quad \alpha C \quad \alpha C$

$K a=\frac{4 \alpha^{3} c^{2}}{1-\alpha}$

and $\alpha=\frac{\wedge}{\wedge 0}$

Where $\alpha$ is the degree of ionization, $\mathrm{C}$ is the molar concentration of the acid, $\Lambda$ and $\Lambda_{o}$ are the equivalent conductances at certain and infinite dilution consecutively. The equivalent conductance $\left(\Lambda, \mathrm{ohm}^{-1} \cdot \mathrm{cm}^{2}\right.$ equi ${ }^{-1}$ ) is estimated using equation (3) . 
$\Lambda=\frac{1000 L}{C}$

Where $\mathrm{L}$ is the specific conductance $\left(\mathrm{ohm}^{-1} \cdot \mathrm{cm}^{-1}\right)$ and $\mathrm{C}$ is the equivalent concentration (equiv.Liter ${ }^{-1}$ ). The conductivity measurements are carried out as follow:

1. A stock solution $\left(1.5 \times 10^{-3}\right.$ equiv. $\left.L^{-1}\right)$ of each imine was prepared by dissolving a certain amount of the compound with $10 \mathrm{ml}$ of absolute ethanol, and then completed to the required volume by deionized water. This solution was then used for the preparation of the other solutions with concentration varied in the range $2.0 \times 10^{-4}$ to $-1.5 \times 10^{-3}$ equiv. $\mathrm{L}^{-1}$. The conductivity of these solutions were measured of various temperatures $\left(20-60^{\circ} \mathrm{C}\right)$. The equivalent conductance is estimated for each of them.

2. The solution with concentration $\left(1.5 \times 10^{-3}\right.$ equi. $\left.\mathrm{L}^{-1}\right)$ of each imine is converted into salt by titration with $\mathrm{NaOH}$ using phenolphthalein as an indicator, then used for the preparation of other solutions, in the same range mentioned above, by dilution and the conductivity measurements are repeated as in point (1) .

\section{Instrumentation}

The following instruments are employed for achieving this research .

1- Water bath: (Searle L200) used for temperature control.

2-Conductometer of type Wissenschaftlich Techniches Werekstatten.

D8120 Welhim .

3- The melting point was measured by melting point SMP30 device of Stuart Company.

4- The relations were drawn by using an Excell office of Word 2007 Personal computer.

\section{Results and Discussion}

\section{Melting points}

Looking at Table (1), one may conclude that, the variation in melting points is due to the type and strength of hydrogen bonding in the three imines considered in this study. The presence of intramolecular hydrogen bond in the Salicylidene-o-hydroxy aniline compound could be the reason of the relative increase in melting point compound to the Salicyliden-mhydroxy aniline and Salicylidene-p- hydroxy aniline compounds while the linearity of the molecule is facilitated the intermolecular hydrogen 
bonding in the Salicylidene-p- hydroxy aniline when compared to the Salicylidene-m-hydroxy aniline imine and was the reason of the relative increase of the melting point.

\section{UV spectra:}

The electronic transition spectroscopy is an efficient method for the prediction of the presence of hydrogen bonds. For this purpose, the UV spectra was recorded in the range of 200-450nm using two solvents of different polarities namely, $\mathrm{CCl}_{4}$ (as non polar solvent) and ethanol (as polar solvent) in order to investigate the presence of hydrogen bonds. Table (2) illustrates the $\lambda$ max obtained in the two solvents, The differences between the wave numbers obtained in the polar and non polar solvents were of positive sign referring to the presence of hydrogen bonds. The type of these bonds cannot be distinguished by using this technique ${ }^{(\mathbf{1 0})}$,so IR spectra were employed for achieving this job.

Values of $\varepsilon_{\max }$ are higher than $1000 \mathrm{~L} . \mathrm{mol}^{-1} . \mathrm{cm}^{-1}$ indicating to electronic transition of $\pi \rightarrow \pi *$ type.

Table (2) : Comparison of the $\lambda$ max values, inpolar and inert solvents and determination of the type of electronic transition.

\begin{tabular}{|c|c|c|c|c|c|c|c|c|}
\hline Comp. & \multicolumn{3}{|c|}{ Solvent $\mathrm{CCl}_{4}$} & \multicolumn{3}{|c|}{ Solvent $\mathrm{C}_{2} \mathrm{H}_{5} \mathrm{OH}$} & \multirow{2}{*}{$\begin{array}{l}\text { Type of } \\
\text { transitio } \\
\mathbf{n} \\
\pi \rightarrow \pi^{*}\end{array}$} & \multirow{2}{*}{$\begin{array}{l}\Delta \overline{\mathbf{u}}(\mathrm{cm}) \\
- \\
2554.84\end{array}$} \\
\hline $\begin{array}{c}\text { Salicylidene-o-hydroxy } \\
\text { aniline }\end{array}$ & 328 & 0.534 & 5340 & 358 & 0.662 & 6620 & & \\
\hline $\begin{array}{c}\text { Salicylidene-m-hydroxy } \\
\text { aniline }\end{array}$ & 330 & 0.609 & 6090 & 344 & 0.641 & 6410 & $\pi \rightarrow \pi^{*}$ & $\begin{array}{l}- \\
1233.26\end{array}$ \\
\hline $\begin{array}{c}\text { Salicylidene-p- hydroxy } \\
\text { aniline }\end{array}$ & 329 & 0.434 & 4340 & 337 & 0.489 & 4890 & $\pi \rightarrow \pi^{*}$ & $\begin{array}{l}- \\
721.539\end{array}$ \\
\hline
\end{tabular}

\section{3- IR Spectra:}

In the beginning, theIR spectra of three Schiff bases were recorded in the solid form by using KBr. The obtained results did not give clear bands discriminating the type of hydrogen bonding. So the spectra were recorded as solutions in the carbon tetra chloride $\left(\mathrm{CCl}_{4}\right)\left(10^{-3}\right.$ and $10^{-4} \mathrm{M}$ concentration)in order to determine the type of hydrogen bond in each compounds. 
The intensities of the O-H band appeared in the rang 3374.05-3446.07 $\mathrm{cm}^{-1}$ were found to be less affected by dilution ${ }^{(\mathbf{1 0})}$ in the ortho compound (Salicylidene-o-hydroxy aniline ), while decreased in the others indicating to the presence of intarmolecular hydrogen bonds in the Salicylidene-mhydroxy aniline and Salicylidene-p- hydroxy aniline compounds. The bands obtained are listed in Table (3) and shows the followings:

1. Broad stretch bands in the range of (3446.07-3374.05) $\mathrm{cm}^{-1}$ referred to the phenolic hydroxide groups.

2. Weak bands in the range (3045.95 to 3061.26$) \mathrm{cm}^{-1}$ referring to the stretch of aromatic $\mathrm{C}-\mathrm{H}$.

3 -Strong bands in the range $(1621.84-1632.82) \mathrm{cm}^{-1}$ indicating to the stretch of $\mathrm{C}=\mathrm{N}$ group.

Table (3): Wave numbers $\left(\mathrm{Cm}^{-1}\right)$ of some important bands of IR spectra recorded in solution of $10^{-4} \mathrm{MCCl}_{4}$ of the considered Schiff bases .

\begin{tabular}{|c|l|l|l|l|}
\hline Compound & $\begin{array}{l}\text { Stretch } \\
\mathrm{C}=\mathrm{N}\end{array}$ & $\begin{array}{l}\text { Stretch } \\
\mathrm{C}-\mathrm{H}\end{array}$ & $\begin{array}{l}\text { Stretch } \\
\text { C- H }\end{array}$ & $\begin{array}{l}\text { Stretch } \\
\text { O- H }\end{array}$ \\
\hline $\begin{array}{c}\text { Salicylidene-o-hydroxy } \\
\text { aniline }\end{array}$ & $1632.82_{(\mathrm{s})}$ & $3045.95_{(\mathrm{w})}$ & $3445.35_{(\mathrm{w})}$ & 3350.91 \\
\hline $\begin{array}{c}\text { Salicylidene-m-hydroxy } \\
\text { aniline }\end{array}$ & $1623.64_{(\mathrm{s})}$ & $3057.89_{(\mathrm{w})}$ & $3374.05_{(\mathrm{w})}$ & 3330.57 \\
\hline $\begin{array}{c}\text { Salicylidene-p- hydroxy } \\
\text { aniline }\end{array}$ & $1621.84_{(\mathrm{s})}$ & $3061.26_{(\mathrm{w})}$ & $3446.07_{(\mathrm{w})}$ & 3340.08 \\
\hline
\end{tabular}

$\mathrm{s}=$ Sharp, $\mathrm{w}=$ Weak, $\mathrm{b}=$ board, $\mathrm{m}=$ medium

\section{Conductivity measurements:}

The aim of this work is to calculate the values of $\mathrm{Ka}$ of the synthesized Schiff bases by conductivity measurements. Scince there are two types of electrolytes ${ }^{(11)}$, strong and weak, an important step must be undertaken in order to test the type of electrolyte that, the considered compounds are belong to ,which enable us to determine the way and choosing the suitable equations, for doing these measurements. For this reason, the Kohlrausch equation (eq .(4)) is selected to carry out this job by plotting the equivalent conductance $(\Lambda)$ versus the square root of concentration of the electrolyte.

$\Lambda=\Lambda_{0}-\mathbf{b} \sqrt{C}$

A straight line must be obtained when applying this equation onto strong electrolytes while curved lines should be obtained for weak electrolytes. 
The plots obtained from the application of equation (4) on the three imines considered in this study and stated in Table (1)at various temperatures are shown in Figure(1).

Figure (1): The relationship between $\Lambda$ against $\sqrt{C}$ at different temperatures $(20-60)^{\circ} \mathrm{C}$ of

Salicylidene Schiff bases Salicylidene-o-hydroxy aniline, Salicylidenem-hydroxy aniline, and Salicylidene-p- hydroxy aniline:

\section{A : Salicylidene-o-hydroxy aniline(SoHA)}

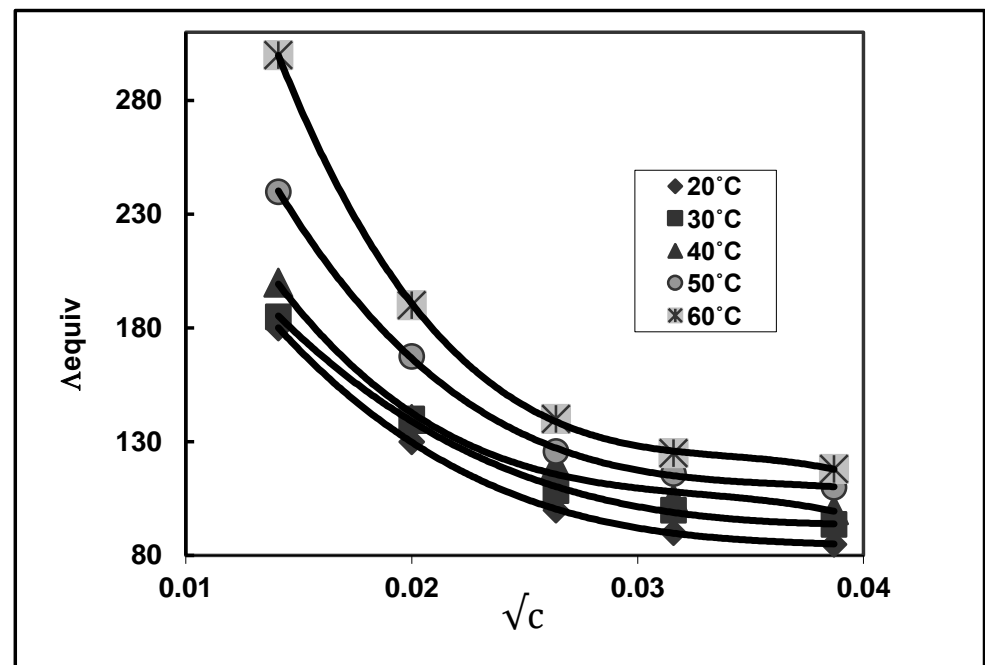

B:

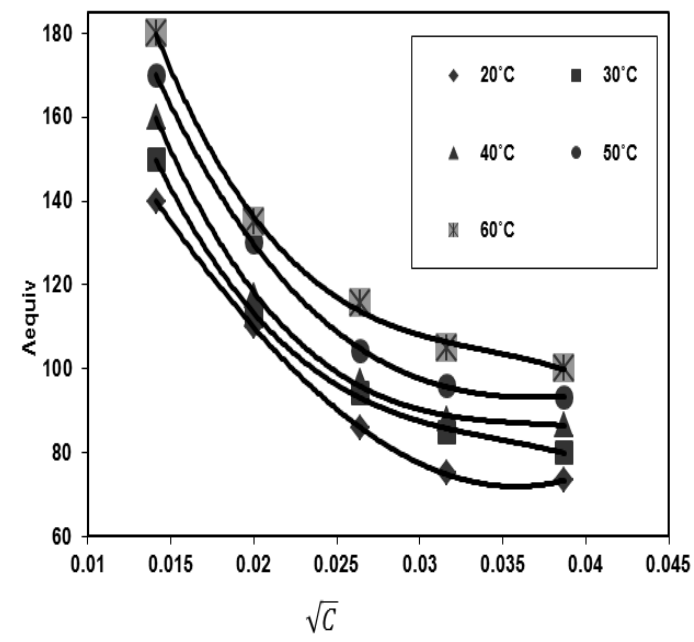

$\underline{\text { Salicylidene-m-hydroxy aniline(SmHA) }}$ 


\section{C: Salicylidene-p- hydroxy aniline(SpHA)}

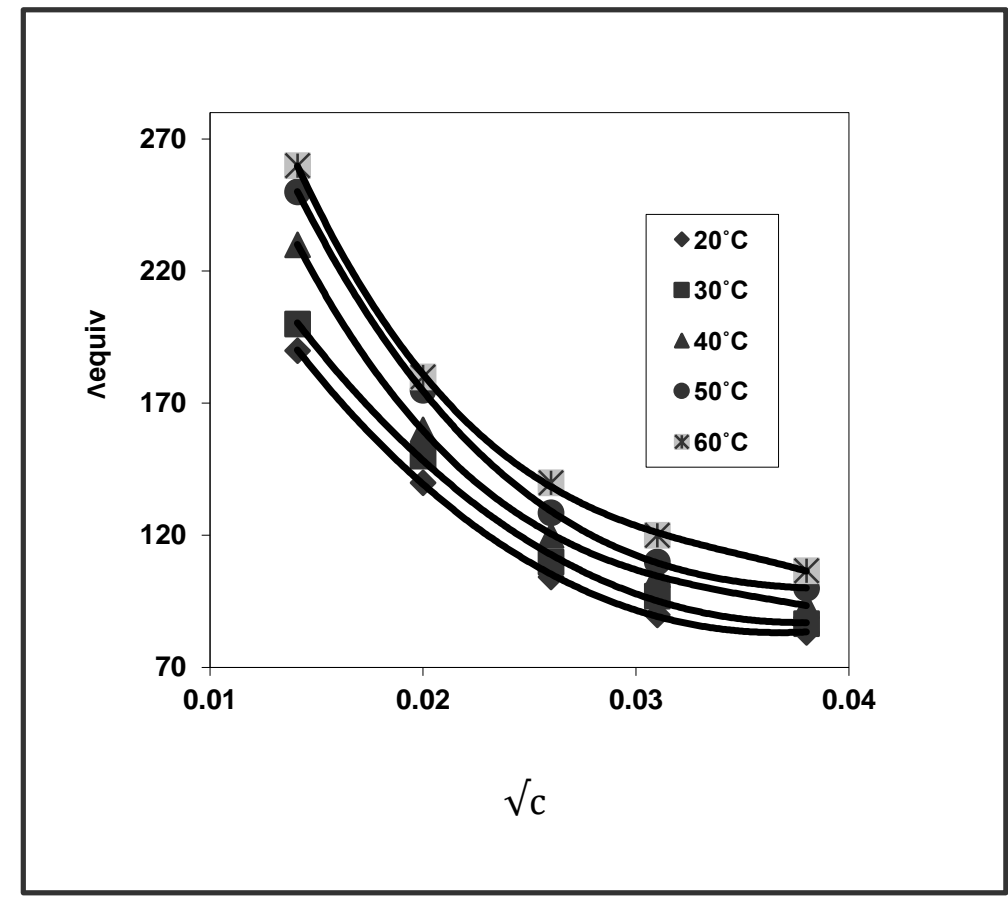

The plots of Figure (1) proved that, these imines are weak electrolytes (weak acids due to the presence of phenolic groups), and equation (4) is not applicable in this case. For this reason, the imines were converted into their conjugated salts and equation (4) is reapplied onto the conductivity data of the salts at various temperatures. Straight lines are obtained in this time (Figure (2)) and they were used for the determination of the values of $\Lambda_{o}$ of the Schiff bases under consideration at various temperatures by employing the following equation:

$\Lambda_{\mathrm{oShiff} \text { base salt }}+\Lambda_{\mathrm{oHCl}}=\Lambda_{\mathrm{oShiff} \text { base (SB) }}+\Lambda_{\mathrm{oNaCl}}$

Since the values of $\Lambda_{\mathrm{oHCl}}$ and $\Lambda_{\mathrm{oNaCl}}$ are known from the literature ${ }^{(12)}$ and $\Lambda_{\mathrm{o}}$ (SB) can be taken from figure(2), $\Lambda_{\mathrm{o}}$ (SB) can be calculated.As an example, for the salicylidene o-hydroxy aniline(SOHA) base

154. $1_{\mathrm{SoAF}(\mathrm{fig}(2)}+390.20=\Lambda_{\mathrm{oSoHA}}+117.10$

$\Lambda_{\mathrm{OSOHA}}=427.2$

The degree of ionization $(\alpha)$ is then calculated using equation (2) and the values of $\mathrm{Ka}$ are estimated at various temperatures.The results obtained are given in Tables (4-6) 
Thermodynamic and Theoretical Studies of average Ionization Constants ...

Figure (2): The relationship between $\Lambda_{\text {equiv }}$ against $\sqrt{C}$ at different temperatures (20-

60) $\mathrm{c}$ resulted from the application of eq.4 on the salicylidene Schiff base salts :

\section{A: Salicylidene- o- hydroxy aniline salt.}
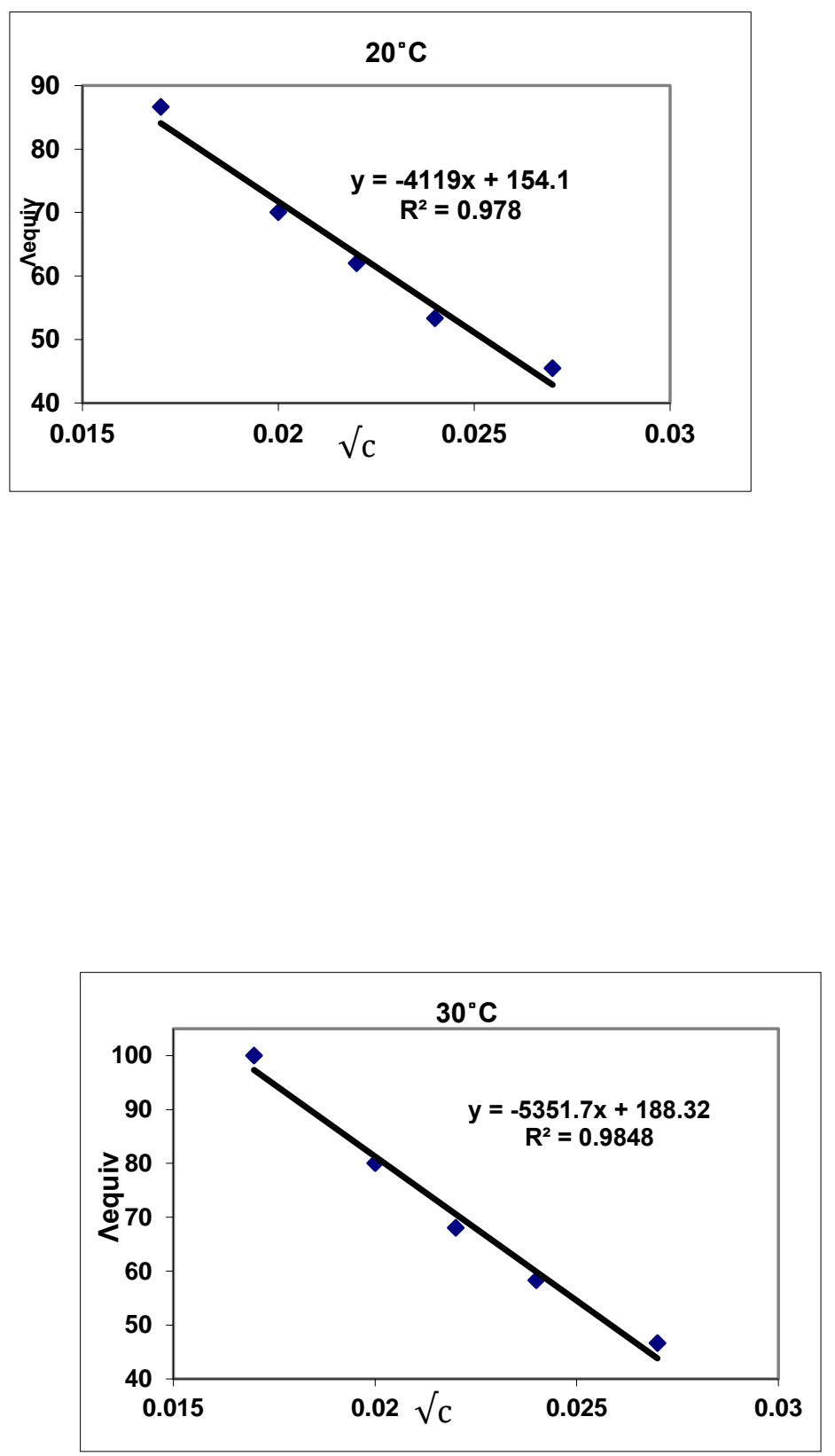
Thermodynamic and Theoretical Studies of average Ionization Constants ...
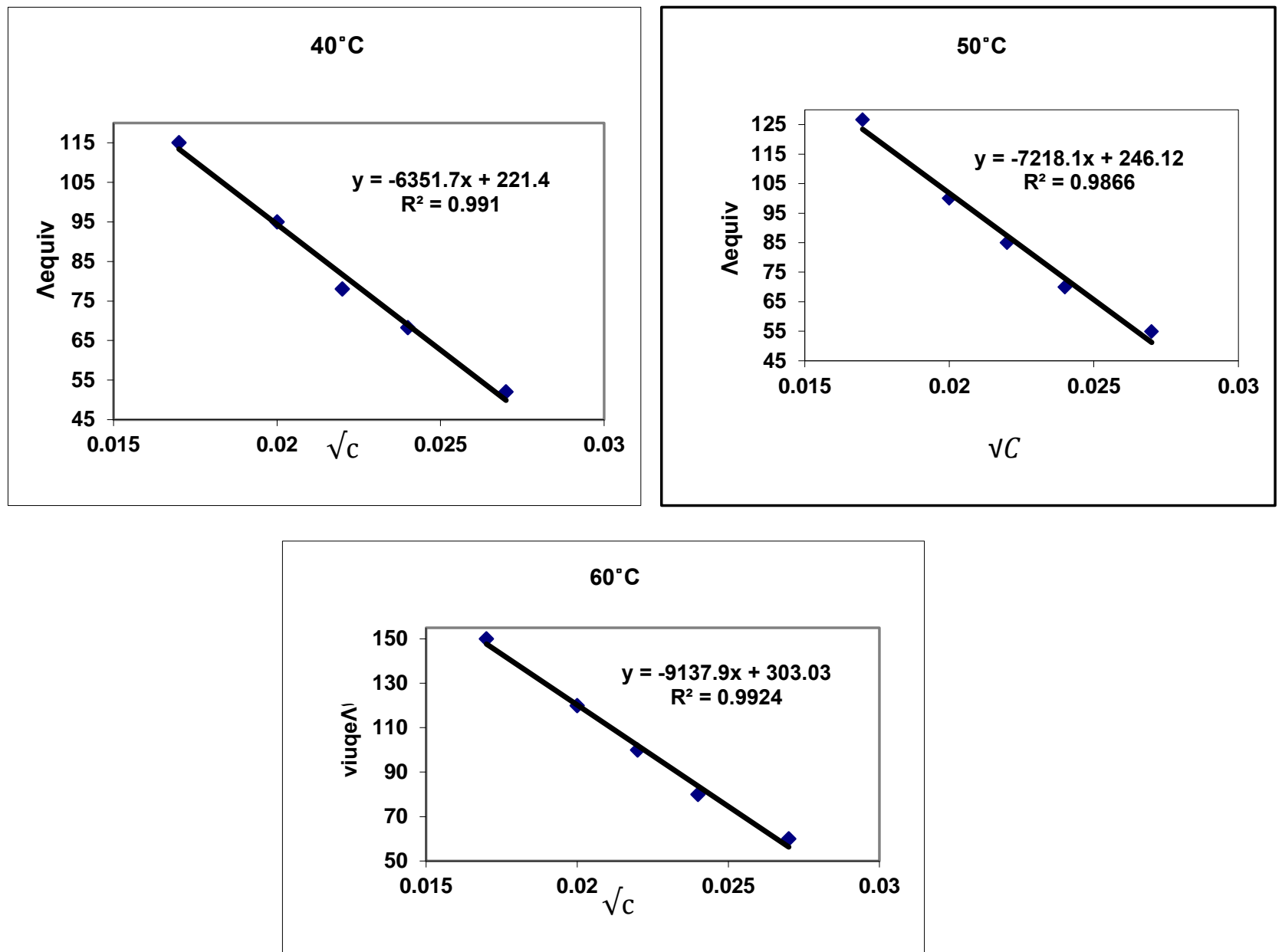

B:Salicylidene-m-hydroxy aniline salt.
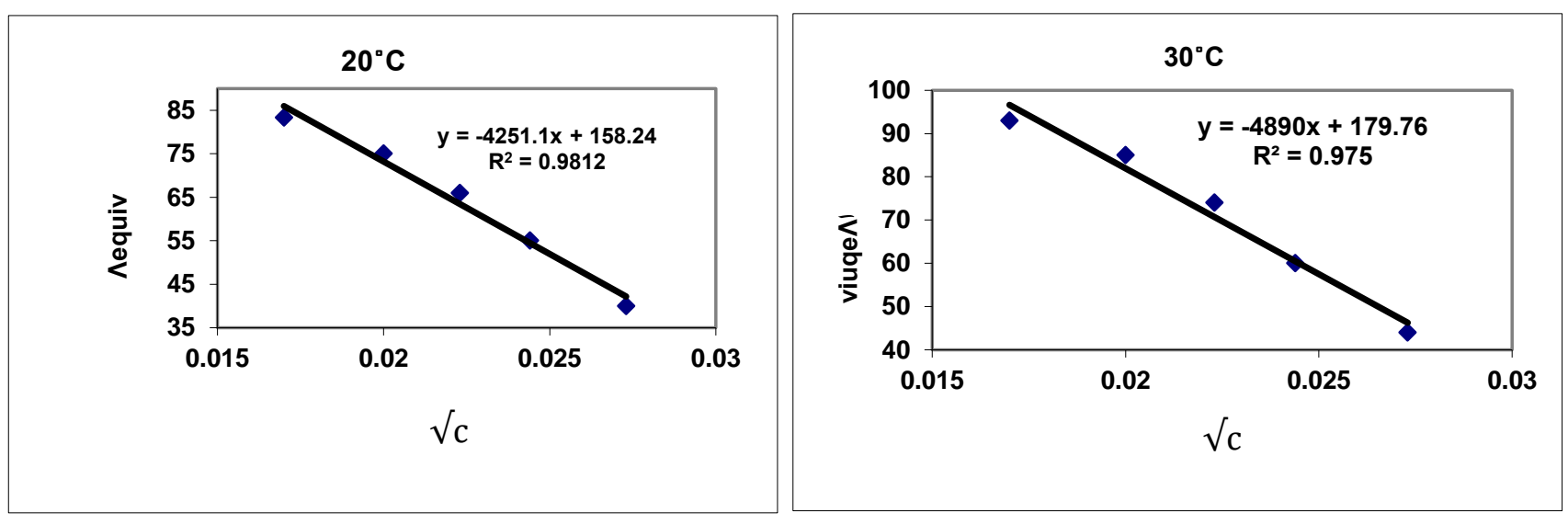
Thermodynamic and Theoretical Studies of average Ionization Constants ...

C: Salicylidene-p-hydroxy aniline salt.

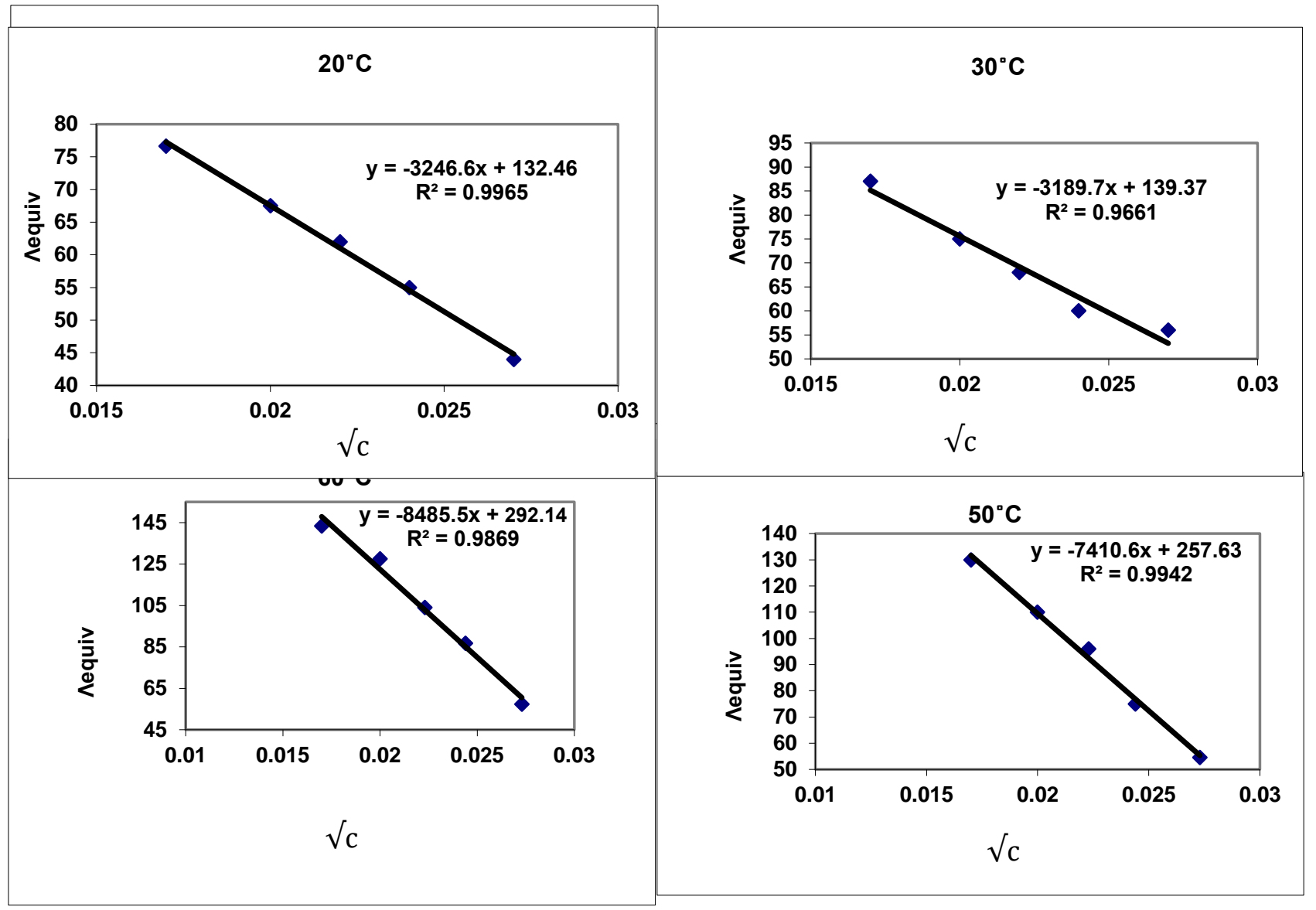


Thermodynamic and Theoretical Studies of average Ionization Constants ...
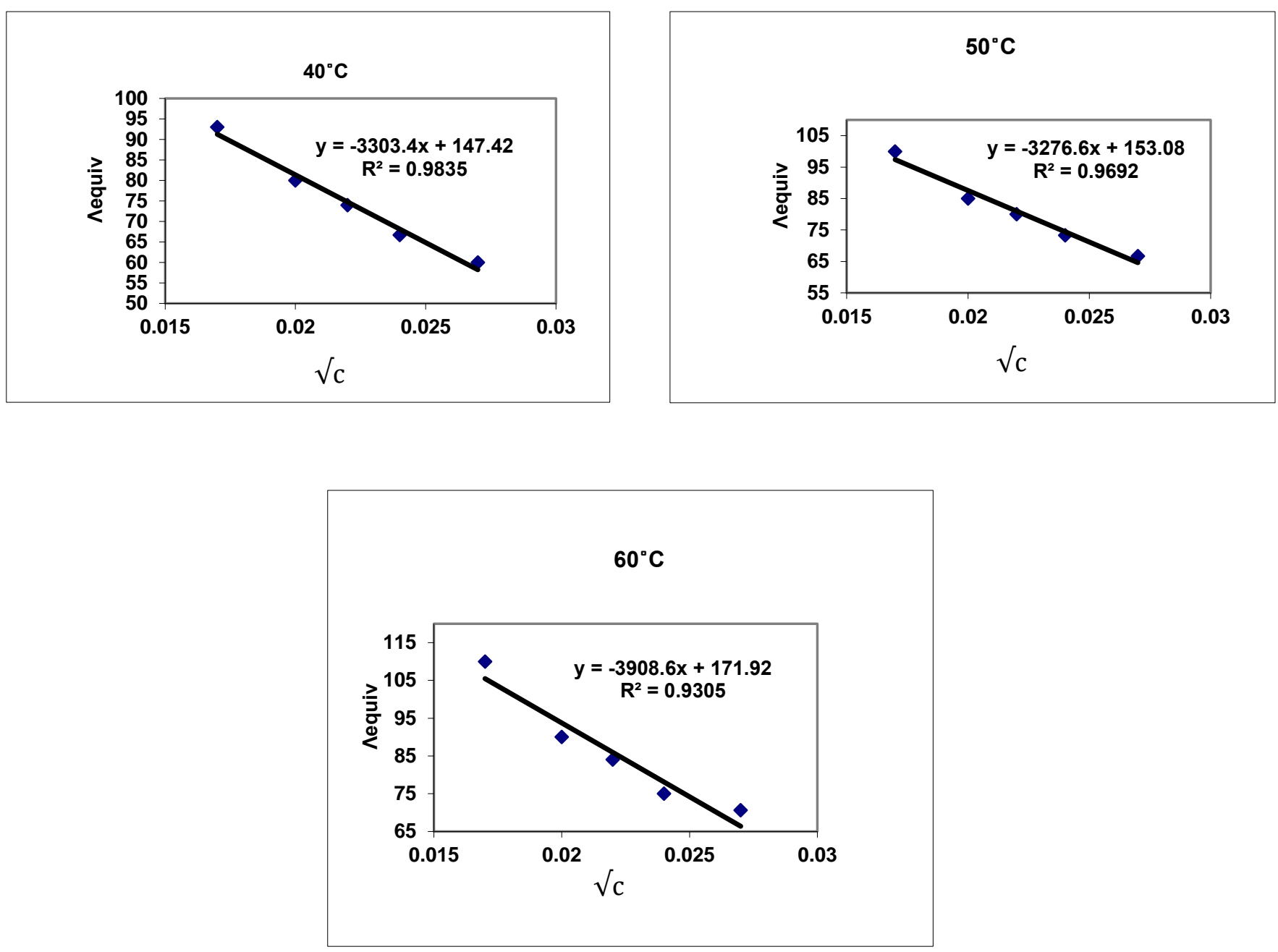
Thermodynamic and Theoretical Studies of average Ionization Constants ...

Table (4) : Equivalent conductance results, degree of ionization Ka of salt/Salicylidene-o-hydroxy aniline imine at various temperatures.

\begin{tabular}{|c|c|c|c|c|c|c|}
\hline $\begin{array}{l}\text { Conc. } \times 10^{3} \\
\text { equiv } / \mathrm{L}\end{array}$ & $T^{\circ} K$ & $\begin{array}{l}\Lambda_{c} \text { of acid } . o m^{-1} \\
. \mathrm{cm}^{2} \text {.equiv }^{-1}\end{array}$ & $\begin{array}{l}\Lambda_{\circ} \text { of Schiff Base } \\
\text { ohm }^{-1} \cdot \mathrm{cm}^{2} \text {.equiv } \\
\text { - }^{-1}\end{array}$ & $\alpha$ & Ka×10-8 & Kà $\times 10^{-8}$ \\
\hline 1.5 & \multirow{5}{*}{293} & 85 & \multirow{5}{*}{427.2} & 0.198 & 8.8 & \multirow{5}{*}{4.02} \\
\hline 1.0 & & 90 & & 0.210 & 4.7 & \\
\hline 0.7 & & 100 & & 0.234 & 3.2 & \\
\hline 0.4 & & 130 & & 0.304 & 1.8 & \\
\hline 0.2 & & 170 & & 0.379 & 1.6 & \\
\hline 1.5 & \multirow{5}{*}{303} & 93.3 & \multirow{5}{*}{495.79} & 0.188 & 7.3 & \multirow{5}{*}{3.4} \\
\hline 1.0 & & 100 & & 0.201 & 4.0 & \\
\hline 0.7 & & 108.57 & & 0.218 & 2.6 & \\
\hline 0.4 & & 140 & & 0.280 & 1.9 & \\
\hline 0.2 & & 185 & & 0.370 & 1.2 & \\
\hline 1.5 & \multirow{5}{*}{313} & 100 & \multirow{5}{*}{563.22} & 0.177 & 6.0 & \multirow{5}{*}{2.84} \\
\hline 1.0 & & 105 & & 0.186 & 3.1 & \\
\hline 0.7 & & 120 & & 0.213 & 2.4 & \\
\hline 0.4 & & 140 & & 0.266 & 1.6 & \\
\hline 0.2 & & 200 & & 0.355 & 1.1 & \\
\hline 1.5 & \multirow{5}{*}{323} & 110 & \multirow{5}{*}{624.30} & 0.176 & 5.9 & \multirow{5}{*}{2.78} \\
\hline 1.0 & & 116 & & 0.185 & 3.1 & \\
\hline 0.7 & & 125.71 & & 0.201 & 1.9 & \\
\hline 0.4 & & 167.5 & & 0.268 & 1.6 & \\
\hline 0.2 & & 240 & & 0.384 & 1.4 & \\
\hline 1.5 & \multirow{5}{*}{333} & 118 & \multirow{5}{*}{713.57} & 0.165 & 4.8 & \multirow{5}{*}{2.24} \\
\hline 1.0 & & 125 & & 0.175 & 2.1 & \\
\hline 0.7 & & 140 & & 0.196 & 1.8 & \\
\hline 0.4 & & 190 & & 0.294 & 2.3 & \\
\hline 0.2 & & 300 & & 0.420 & 2.0 & \\
\hline
\end{tabular}


Thermodynamic and Theoretical Studies of average Ionization Constants ...

Table (5) : Equivalent conductance results, degree of ionization and average ionization constant of salt/Salicylidene-m-hydroxy aniline imine at various temperatures.

\begin{tabular}{|c|c|c|c|c|c|c|}
\hline $\begin{array}{l}\text { Con. } \times 10^{3} \\
\text { equiv } / L\end{array}$ & $\mathrm{~T}^{\mathrm{D}} \mathrm{K}$ & $\begin{array}{l}\Lambda \Lambda_{\mathrm{c}} \text { of acid. } \\
\mathrm{ohm}^{-1} \\
. \mathrm{cm}^{2} \text {.equiv }\end{array}$ & $\begin{array}{l}\Lambda_{0} \text { of Shiff Base.ohm } \\
\text {.cm }^{-1} \text {.equiv }\end{array}$ & $\alpha$ & $\mathrm{Ka} \times 10^{-8}$ & $\begin{array}{l}\text { Kà×10 } \\
8\end{array}$ \\
\hline 1.5 & \multirow{5}{*}{293} & 73.33 & \multirow{5}{*}{431.34} & 0.170 & 5.3 & \multirow{5}{*}{2.36} \\
\hline 1.0 & & 75 & & 0.173 & 2.5 & \\
\hline 0.7 & & 85.7 & & 0.198 & 1.8 & \\
\hline 0.4 & & 110 & & 0.255 & 1.4 & \\
\hline 0.2 & & 140 & & 0.324 & 0.8 & \\
\hline 1.5 & \multirow{5}{*}{303} & 80 & \multirow{5}{*}{487.25} & 0.164 & 4.7 & \multirow[t]{5}{*}{2.1} \\
\hline 1.0 & & 85 & & 0.174 & 2.5 & \\
\hline 0.7 & & 94.28 & & 0.193 & 1.7 & \\
\hline 0.4 & & 112.5 & & 0.230 & 1.0 & \\
\hline 0.2 & & 150 & & 0.307 & 0.6 & \\
\hline 1.5 & \multirow{5}{*}{313} & 86.6 & \multirow{5}{*}{551.39} & 0.157 & 4.1 & \multirow{5}{*}{1.7} \\
\hline 1.0 & & 88 & & 0.159 & 1.9 & \\
\hline 0.7 & & 97.1 & & 0.176 & 1.2 & \\
\hline 0.4 & & 117.5 & & 0.213 & 0.8 & \\
\hline 0.2 & & 160 & & 0.290 & 0.5 & \\
\hline 1.5 & \multirow{5}{*}{323} & 93.3 & \multirow{5}{*}{633.81} & 0.147 & 3.3 & \multirow{5}{*}{1.38} \\
\hline 1.0 & & 96 & & 0.151 & 1.6 & \\
\hline 0.7 & & 104.28 & & 0.164 & 1.0 & \\
\hline 0.4 & & 130 & & 0.205 & 0.6 & \\
\hline 0.2 & & 170 & & 0.268 & 0.4 & \\
\hline 1.5 & \multirow{5}{*}{333} & 100 & \multirow{5}{*}{702.68} & 0.142 & 3.0 & \multirow{5}{*}{1.26} \\
\hline 1.0 & & 105 & & 0.149 & 1.5 & \\
\hline 0.7 & & 115.71 & & 0.164 & 1.0 & \\
\hline 0.4 & & 135 & & 0.192 & 0.5 & \\
\hline 0.2 & & 180 & & 0.256 & 0.3 & \\
\hline
\end{tabular}


Thermodynamic and Theoretical Studies of average Ionization Constants ...

Table (6) : Equivalent conductance results, degree of ionization ka of salt/Salicylidene-p- hydroxy aniline imine at various temperatures.

\begin{tabular}{|c|c|c|c|c|c|c|}
\hline $\begin{array}{l}\text { Conc } \\
\times 10^{3} \\
\text { equiv } / L\end{array}$ & $T^{\circ} K$ & 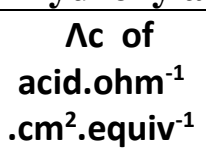 & $\begin{array}{l}\Lambda \circ o f \text { Shiff Base } \\
\text { ohm }^{-1} \cdot \mathrm{cm}^{2} . \text { equiv }\end{array}$ & $\alpha$ & Ka×10 $0^{-8}$ & Kà $\times 10^{-8}$ \\
\hline 1.5 & \multirow{5}{*}{293} & 83.33 & \multirow{5}{*}{405.56} & 0.205 & 9.7 & \multirow[t]{5}{*}{5.32} \\
\hline 1.0 & & 90 & & 0.221 & 5.5 & \\
\hline 0.7 & & 104.28 & & 0.257 & 4.4 & \\
\hline 0.4 & & 140 & & 0.345 & 4.0 & \\
\hline 0.2 & & 190 & & 0.468 & 3.0 & \\
\hline 1.5 & \multirow{5}{*}{303} & 86.66 & \multirow{5}{*}{446.831} & 0.193 & 8.0 & \multirow{5}{*}{4.90} \\
\hline 1.0 & & 97 & & 0.217 & 6.6 & \\
\hline 0.7 & & 110 & & 0.246 & 3.8 & \\
\hline 0.4 & & 150 & & 0.335 & 3.6 & \\
\hline 0.2 & & 200 & & 0.447 & 2.5 & \\
\hline 1.5 & \multirow{5}{*}{313} & 93.33 & \multirow{5}{*}{489.24} & 0.190 & 7.6 & \multirow{5}{*}{4.54} \\
\hline 1.0 & & 105 & & 0.214 & 4.9 & \\
\hline 0.7 & & 120 & & 0.245 & 3.8 & \\
\hline 0.4 & & 160 & & 0.327 & 3.3 & \\
\hline 0.2 & & 230 & & 0.470 & 3.1 & \\
\hline 1.5 & \multirow{5}{*}{323} & 100 & \multirow{5}{*}{529.24} & 0.188 & 7.3 & \multirow{5}{*}{4.36} \\
\hline 1.0 & & 110 & & 0.207 & 4.4 & \\
\hline 0.7 & & 128.57 & & 0.242 & 3.6 & \\
\hline 0.4 & & 175 & & 0.330 & 3.4 & \\
\hline 0.2 & & 250 & & 0.472 & 3.1 & \\
\hline 1.5 & \multirow{5}{*}{333} & 106.66 & \multirow{5}{*}{582.45} & 0.183 & 6.7 & \multirow{5}{*}{3.96} \\
\hline 1.0 & & 120 & & 0.206 & 4.4 & \\
\hline 0.7 & & 140 & & 0.240 & 3.5 & \\
\hline 0.4 & & 180 & & 0.309 & 2.7 & \\
\hline 0.2 & & 260 & & 0.446 & 2.5 & \\
\hline
\end{tabular}


Looking at the results listed in Tables (4-6), we could reach to the following:

1. The increase of temperature decreasing the acidity (ionization) of the studied imines. This result is consistent with other study found in the literature ${ }^{(13)}$.

2. At constant temperature, the acidity of the studied compounds varied in the Following order : Salicylidene-p-hydroxy aniline $>$ Salicylidene-ohydroxy aniline >Salicylidene-m-hydroxy aniline

This phenomena could be attributed to the relative stability of the phenoxideion formed from the ionization of the investigated compounds which varied as a result of the charge distribution over two rings in the Salicylidene-p- hydroxy aniline and Salicylidene-o-hydroxy aniline molecules while it is restricted over on ring in the Salicylidene-m-hydroxy aniline molecule as illustrated in following :

Salicylidene-o-hydroxy aniline

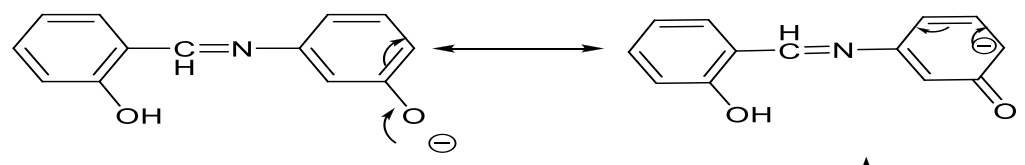

Salicylidene-m-hydroxy aniline
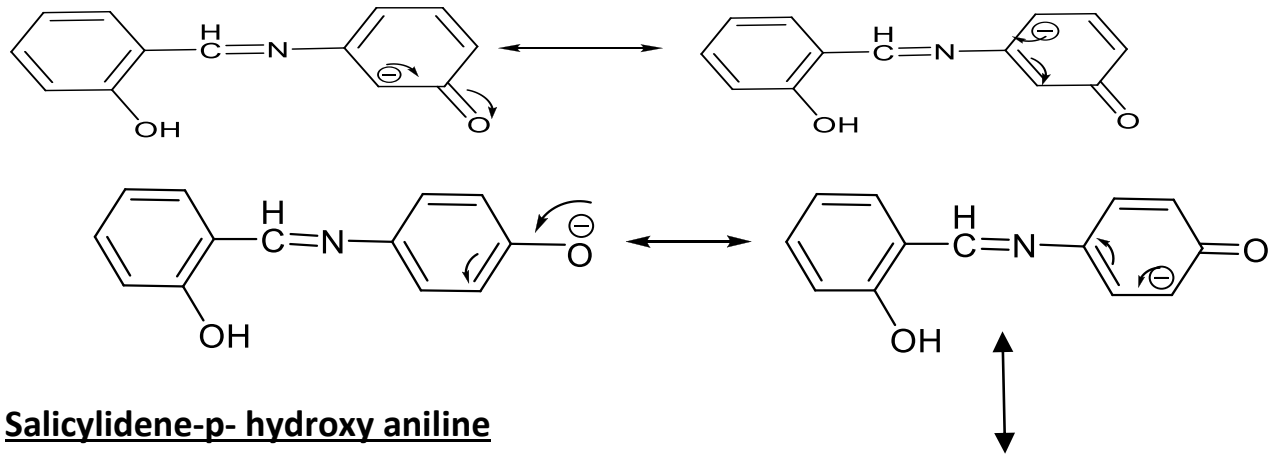

Salicylidene-p- hydroxy aniline

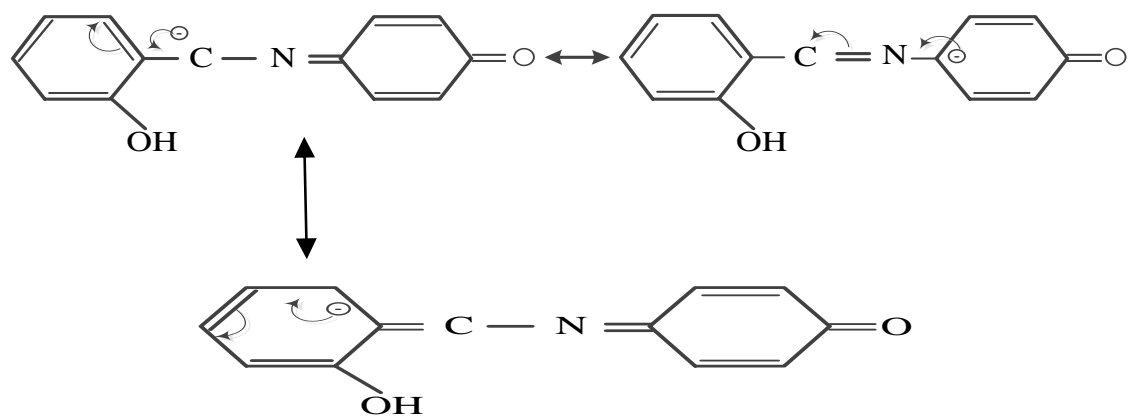


Diagram (1): shaped formed as a results of resonance in the SmHA and Salicylidene-p- hydroxy aniline compounds. The relative increase in acidity of the Salicylidene-p- hydroxy aniline with respect to the Salicylidene-o-hydroxy aniline may due to the intramolecular hydrogen bonding present in the later.

\section{5- Thermodynamic study:}

The thermodynamic study is carried out depending on the data obtained from the determination of the values of $\mathrm{Ka}$ at various temperatures(20$\left.60^{\circ} \mathrm{c}\right)$. The change in the free energy of Gibbs $\left(\Delta \mathrm{G}^{\circ}\right)$ is calculated from equation (5).

$\Delta \mathbf{G}^{\circ}=-\mathrm{RT} \ln K \mathrm{a}$

The valuesof $\Delta \mathrm{H}^{\circ}$ of ionization is estimated by applying Vant Hoff's equation (equation(6)).

Ln ka $=$ constant $-\Delta \mathbf{H}^{\circ} / \mathbf{R T}$

The plot of $\operatorname{lnKa}$ versus $1 / \mathrm{T}$ gives straight line with slope equal to $-\Delta \mathrm{H}^{\circ}$ $/ R$ (see Figures(3)).Equation (7) is used for determination of $\Delta S^{\circ}$.

$\Delta \mathbf{G}^{\circ}=\Delta \mathbf{H}^{\circ}-\mathbf{T} \Delta \mathbf{S}^{\circ}$

Figure (3): Relation between $\log$ Ka versus 1/T for Salicylidene-o-hydroxy aniline , Salicylidene-m-hydroxy aniline, and Salicylidene-p- hydroxy aniline bases.
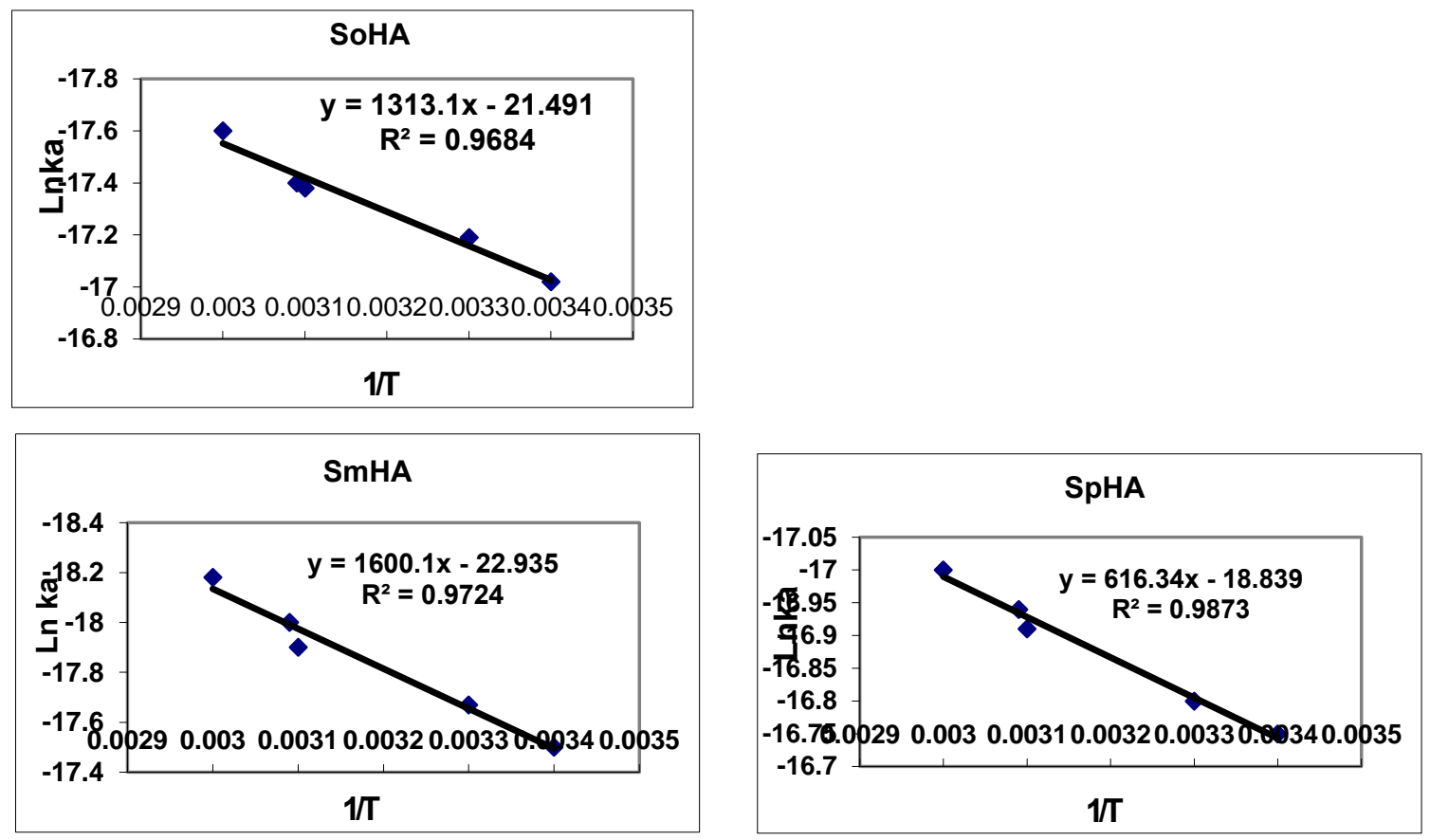
The obtained values of the thermodynamic functions $\left(\Delta \mathrm{G}^{\circ}, \Delta \mathrm{H}^{\circ}\right.$ and $\left.\Delta \mathrm{S}^{\circ}\right)$ for the studied systems are listed in Table (7)

Table (7) : Results of the thermodynamic study.

a-Salicylidene -o- hydroxy aniline.

\begin{tabular}{|c|c|c|c|c|c|}
\hline $\mathrm{T}^{\circ} \mathrm{K}$ & $\begin{array}{l}\Delta \mathrm{H}^{\circ} \\
\mathrm{kJ} . \mathrm{mol}^{-1}\end{array}$ & $\begin{array}{l}\Delta \mathrm{H}^{\circ} \\
\mathrm{kJ} \cdot \mathrm{mol}^{-1}\end{array}$ & $\begin{array}{l}\Delta \mathrm{G}^{\circ} \\
\mathrm{kJ} \cdot \mathrm{mol}^{-1}\end{array}$ & $\begin{array}{l}\Delta \mathrm{G}^{\circ} \\
\mathrm{kJ} \cdot \mathrm{mol}^{-1}\end{array}$ & $\begin{array}{l}\Delta \mathrm{S}^{\circ} \\
\text { J.mol }{ }^{-1} \cdot \mathrm{k}^{-1}\end{array}$ \\
\hline 293 & -10.891 & \multirow{5}{*}{-10.842} & 41.460 & \multirow{5}{*}{45.084} & \multirow{5}{*}{-178.676} \\
\hline 303 & -10.840 & & 43.304 & & \\
\hline 313 & -10.724 & & 45.201 & & \\
\hline 323 & -11.012 & & 46.699 & & \\
\hline 333 & -10.744 & & 48.754 & & \\
\hline
\end{tabular}

b-Salicylidene -m-hydroxy aniline.

\begin{tabular}{|c|c|c|c|c|c|}
\hline $\mathrm{T}^{\circ} \mathrm{K}$ & $\begin{array}{l}\Delta \mathrm{H}^{\circ} \\
\mathrm{kJ} \cdot \mathrm{mol}^{-1}\end{array}$ & $\begin{array}{l}\Delta \mathrm{H}^{\circ} \\
\mathrm{kJ} \cdot \mathrm{mol}^{-1}\end{array}$ & $\begin{array}{l}\Delta \mathrm{G}^{\circ} \\
\mathrm{kJ} \cdot \mathrm{mol}^{-1}\end{array}$ & $\begin{array}{l}\Delta \mathrm{G}^{\circ} \\
\mathrm{kJ} \cdot \mathrm{mol}^{-1}\end{array}$ & $\begin{array}{l}\Delta \mathrm{S}^{\circ} \\
\mathrm{J} \cdot \mathrm{mol}^{-1} \cdot \mathrm{k}^{-1}\end{array}$ \\
\hline 293 & -13.093 & \multirow{5}{*}{-13.126} & 42.776 & \multirow{5}{*}{46.556} & \multirow{5}{*}{-190.681} \\
\hline 303 & -13.263 & & 44.513 & & \\
\hline 313 & -13.128 & & 46.554 & & \\
\hline 323 & -13.010 & & 48.579 & & \\
\hline 333 & -13.136 & & 50.360 & & \\
\hline
\end{tabular}

c- Salicylidene -p-hydroxy aniline.

\begin{tabular}{|c|c|c|c|c|c|}
\hline $\mathrm{T}^{\circ} \mathrm{K}$ & $\begin{array}{l}\Delta \mathrm{H}^{\circ} \\
\mathrm{kJ} \cdot \mathrm{mol}^{-1}\end{array}$ & $\begin{array}{l}\Delta \mathrm{H}^{\circ} \\
\mathrm{kJ} \cdot \mathrm{mol}^{-1}\end{array}$ & $\begin{array}{l}\Delta \mathrm{G}^{\circ} \\
\mathrm{kJ} \cdot \mathrm{mol}^{-1}\end{array}$ & $\begin{array}{l}\Delta \mathrm{G}^{\circ} \\
\mathrm{kJ} \cdot \mathrm{mol}^{-1}\end{array}$ & $\begin{array}{l}\Delta \mathrm{S}^{\circ} \\
\text { J.mol }{ }^{-1} \cdot \mathrm{k}^{-1}\end{array}$ \\
\hline 293 & -5.088 & \multirow{5}{*}{-5.054} & 40.803 & \multirow{5}{*}{43.969} & \multirow{5}{*}{-156.627} \\
\hline 303 & -5.060 & & 42.397 & & \\
\hline 313 & -5.045 & & 43.978 & & \\
\hline 323 & -5.099 & & 45.491 & & \\
\hline 333 & -4.980 & & 47.176 & & \\
\hline
\end{tabular}


The results of Table(7) indicate the following:

1. The $\Delta \mathrm{G}^{\circ}$ of the ionization reaction of the studied systems are positive values, which means that, these reaction are non spontaneous. This result could be understood since the hydrogen of the phenolic groups of such weak acids are connected to the oxygen atom by covalent bonds and difficult to be ionized in aqueous solution.

2. The ionization reactions of the studied system are exothermic processes indicated by the negative values of $\Delta \mathrm{H}^{\circ}$.

3. The negative values of $\Delta \mathrm{S}^{\circ}$ of the investigated system gives indication to the increase of the order of these system. Such contradiction with the expected results could be illustrated in terms of the rise of various type of molecular association and/ or inter and intramolecular hydrogen bonding. These results are consistent with other study found in the literature ${ }^{(14)}$.

4. The values of $\Delta \mathrm{H}^{\circ}$ of the ionization reactions of the considered systems are reversely proportional with the values of Ka. This means that, the increase of $\mathrm{Ka}$ is resulted from weakening of the $\mathrm{O}-\mathrm{H}$ bond and decreasing the non spontaneity of the ionization.

\begin{tabular}{|c|c|c|c|}
\hline & $\begin{array}{l}\text { Salicylidene-p- } \\
\text { hyhydroxy aniline }\end{array}$ & $\begin{array}{l}\text { Salicylidene-o- } \\
\text { hydroxy anline }\end{array}$ & $\begin{array}{l}\text { Salicylidenene-m- } \\
\text { hydroxy aniline }\end{array}$ \\
\hline$\Delta \mathrm{H}\left(\mathrm{KJ}^{\prime} \mathrm{mol}^{-1}\right)$ & -5.055 & -8.663 & -13.126 \\
\hline$\Delta \mathrm{G}^{\circ}\left(\mathrm{KJ}^{\prime} \mathrm{mol}^{-1}\right)$ & 43.969 & 46.556 & 45.084 \\
\hline $\mathrm{Ka} \times 10^{-8}$ & 5.32 & 4.02 & 2.36 \\
\hline
\end{tabular}

\section{6- Estimation of $\Lambda \mathrm{o}\left(\right.$ at $\left.^{\circ}{ }^{\circ} \mathrm{C}\right)$ of the ionization reaction:}

According to the results listed in Tables (4-6), the values of the $\Lambda_{\mathrm{o}}$ obtained at various temperatures are used to estimate their values at $\left(25^{\circ} \mathrm{C}\right)$ by employing ${ }^{(11)}$ equation (8)

$\Lambda_{\mathrm{o}(\mathrm{t})}=\Lambda_{\mathrm{o}(25)}+\mathrm{B} \Lambda_{\mathrm{o}(25)}(\mathrm{t}-25)$

Where $\Lambda_{o(t)}$ is the equivalent conductance at infinite dilution at any temperature. $\Lambda_{\mathrm{o}(25)}$ is the equivalent conductance at infinite dilution at $25^{\circ} \mathrm{C},(\mathrm{t})$ is the temperature $\left({ }^{\circ} \mathrm{C}\right)$ and $\mathrm{B}$ is a constant, its value depends on the type and structure of the studied acid. According toequation (8), values of $\Lambda_{0}$ are directly proportional to the temperature and the plot of $\Lambda_{\mathrm{o}(\mathrm{t})}$ against(t-25) should gives a straight line with intercept equal to the $\Lambda_{\mathrm{o}(25)}$ and slope $\mathrm{B} \Lambda_{\mathrm{o}(25)}$. 
The application of equation (8) on the data obtained for the compounds listed in Tables (4-6) gave very good linear relationships shown in figure (4) indicated by correlation coefficient $\left(\mathrm{R}^{2}\right)$ values close to unity. The values of the evaluated $\Lambda_{o(25)}$, constant Band $\mathrm{R}^{2}$ are given in Table (8).

Table (8):Results obtained from the application of eq. (8) on the data of Tables(4-6).

\begin{tabular}{||l|c|l|l|}
\hline Comp. & $\Lambda_{\mathrm{o}(25)}\left(\mathrm{ohm}^{-1} \cdot \mathrm{cm}^{2}\right.$.equiv $\left.{ }^{-1}\right)$ & $\mathrm{B}$ & $\mathrm{R}^{2}$ \\
\hline o-hydroxy aniline & 459.6 & 0.0152 & 0.996 \\
\hline Salicylidene- & & & \\
m-hydroxy aniline & 457.9 & 0.0150 & 0.995 \\
\hline Salicylidene- & & 0.0120 & 0.997 \\
p- hydroxy aniline & 425.2 & & \\
\hline
\end{tabular}

The results of Table (8) show that, the values of $\Lambda_{o(25)}$ lie in the range between the values obtained at $\Lambda_{o(20)}$ and $\Lambda_{o(30)}$ indicated in the tables (46 ) and the values of $\Lambda_{o}$ vary linearly with temperature

Fig(4): The application of equation (8) on the data of the studied compounds.
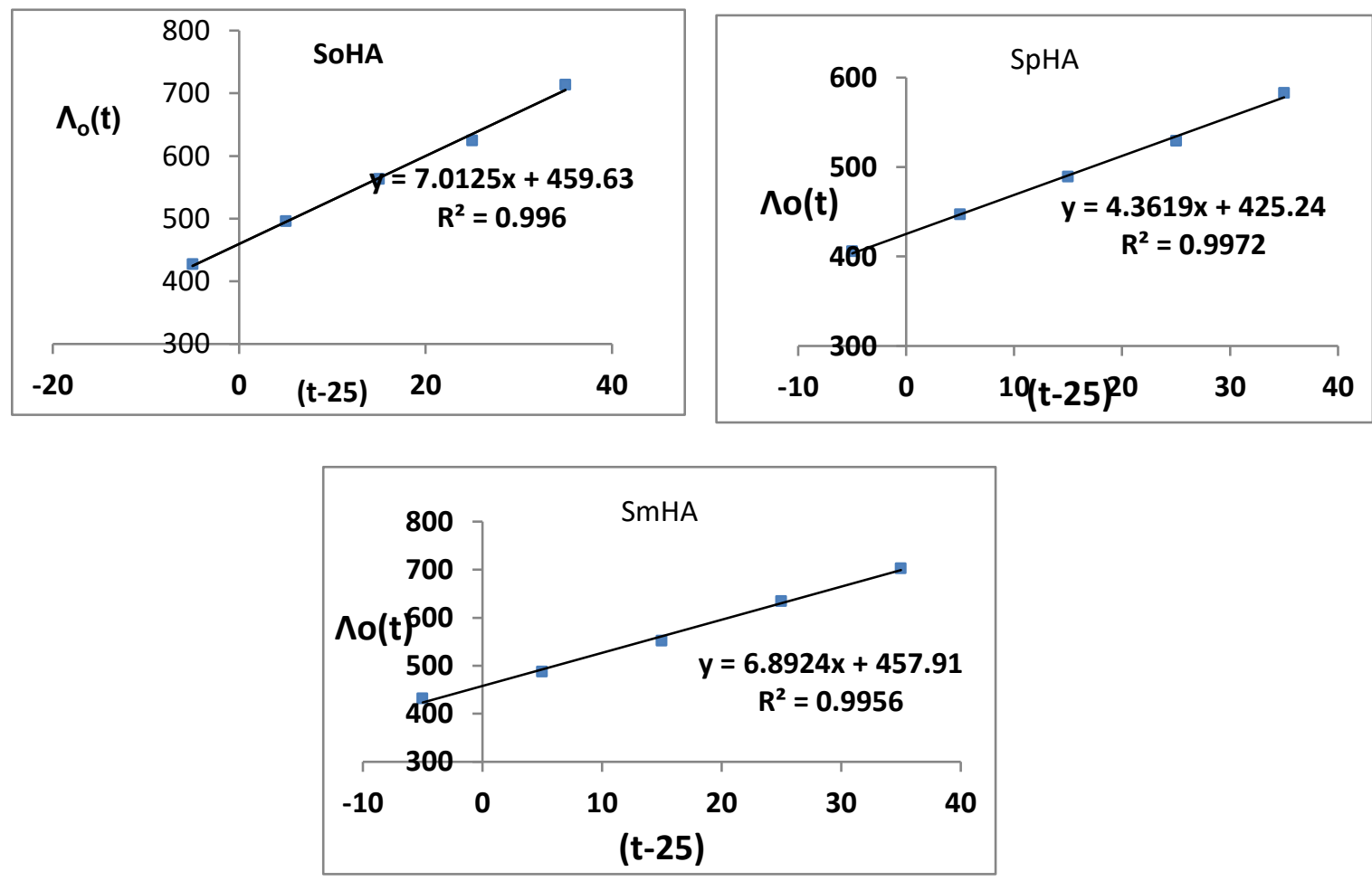


\section{7- Theoretical Calculations:}

In this work, the semiempirical Austin method(AM1) ${ }^{(15)}$ is used for achieving the calculation of a number of structural and energetic parameters relating to the weak acids considered in this investigation and to their salts. The parameters included the total energy (TE) of the molecule (which represent the sum of several spatial interactions and structural distortions), the electronic charge exist on the hetro atoms of the molecules and the energies of the highest occupied molecular orbital (HOMO) and the lowest unoccupied molecular orbital (LUMO). Additional Parameters are calculated depending on the values of the energy of (HOMO, $\left.\mathrm{E}_{\text {HOMO }}\right)$ And (LUMO) , $\left.\mathrm{E}_{\text {LUMO }}\right)$ orbitals ${ }^{(\mathbf{1 6 - 1 7 )}}{ }^{\text {,known as }}$ the hardness $(\eta)$, electronic chemical Potential $(\mu)$ and global electrophilicity index $(\omega)$. These parameters are determined by Equations $(9,10$, and 11$)$ respectively.

$$
\begin{array}{r}
\eta=1 / 2 \quad\left(\mathbf{E}_{\text {LUMо }}-\mathbf{E}_{\text {Hомо }}\right) \ldots . . . .(9) \\
\mu=1 / 2 \quad\left(\mathbf{E}_{\text {Hомо }}+\mathbf{E}_{\text {LUMo }}\right) \ldots \ldots . .(10) \\
\omega=\eta^{2} / 2 \eta \ldots . .
\end{array}
$$

The values of the calculated parameters are listed in Tables (9-11). They are used for comparing the structures of the acids and their salts trying to find out the relation between these variables and the values of Ka.

Table (9) : Values of the energies resulted from structural distortions for the acids and their salts .

\begin{tabular}{|l|l|l|l|l|l|l|l|l|}
\hline \multicolumn{1}{|c|}{$\begin{array}{l}\text { Comp. } \\
\text { Stretch }\end{array}$} & Bend & S-t* & Torsion & Non, & $\mathbf{1 , 4}$ VDW $^{* *}$ & Charge & TE \\
\hline $\begin{array}{l}\text { Salicylidene-o- } \\
\text { hydroxy aniline }\end{array}$ & 0.3386 & 2.9569 & 0.0648 & 0.0649 & -1.3434 & 4.5942 & $\ldots$. & $\begin{array}{l}\text { Kcal/mol } \\
\text { VDW }\end{array}$ \\
\hline $\begin{array}{l}\text { Salicylidene-m- } \\
\text { hydroxy aniline }\end{array}$ & 0.3235 & 1.6481 & 0.0514 & 0.0191 & -0.6194 & 4.2615 & $\ldots .725$ \\
\hline $\begin{array}{l}\text { Salicylidene-p- } \\
\text { hydroxy aniline }\end{array}$ & 0.3230 & 1.5407 & 0.0511 & 0.4224 & -0.6873 & 4.2564 & $\ldots .$. & 5.684 \\
\hline \begin{tabular}{l} 
Salicylidene-o- \\
\hline
\end{tabular} & 0.4501 & 3.7092 & 0.0017 & 0.0081 & 28.497 & 6.7097 & -273.188 & -233.815 \\
\hline
\end{tabular}


Thermodynamic and Theoretical Studies of average Ionization Constants ...

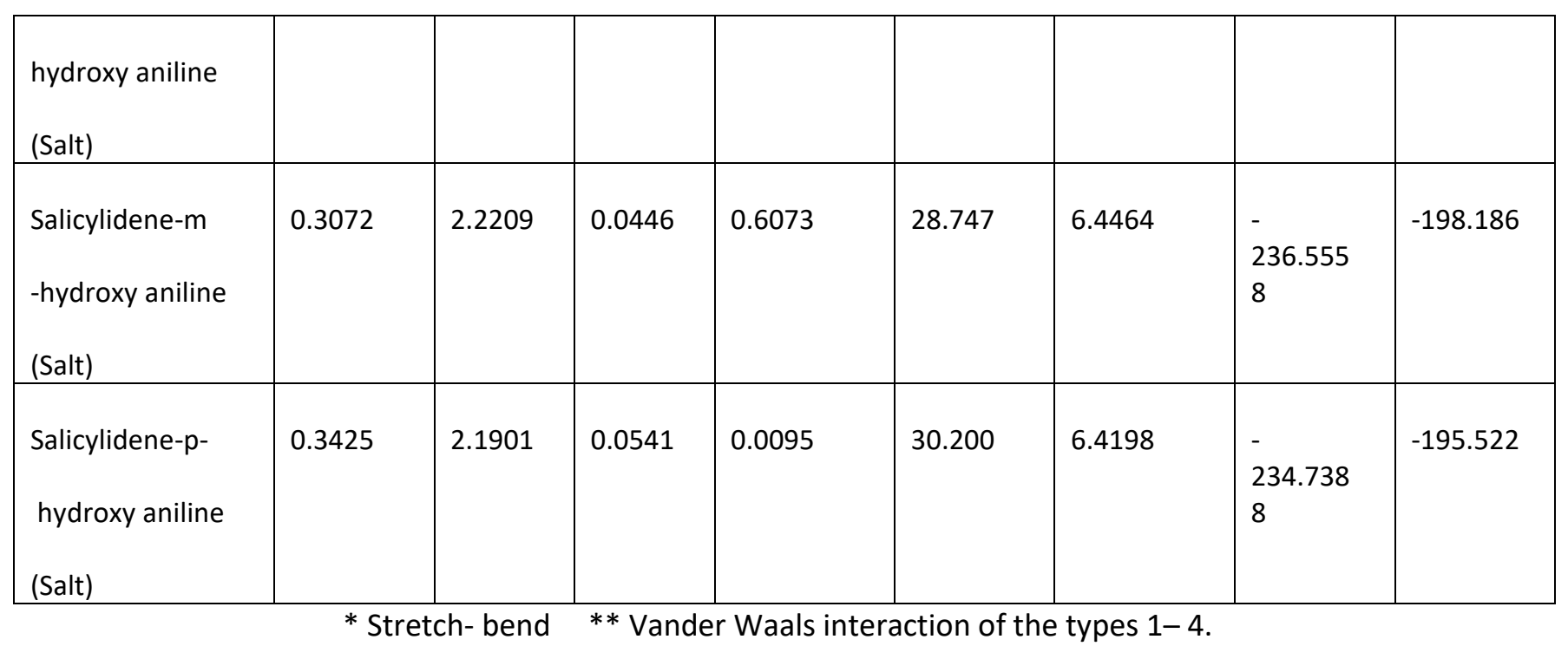

Table (10) : Values of Eномо, ELumo, $\eta, \mu$ and $\omega$ of acids and their salts .

\begin{tabular}{|c|c|c|c|c|c|c|}
\hline Comp. & $\begin{array}{l}\text { Еномо } \\
\text { ev }\end{array}$ & $\begin{array}{l}\text { Elumo } \\
\text { ev }\end{array}$ & $E_{\text {L-H }}$ & $\eta$ & $\mu$ & $\omega$ \\
\hline $\begin{array}{l}\text { Salicylidene-o- } \\
\text { hydroxy aniline }\end{array}$ & -9.279 & -5.077 & 4.202 & 2.101 & -7.178 & 12.261 \\
\hline $\begin{array}{l}\text { Salicylidene-m- } \\
\text { hydroxy aniline }\end{array}$ & -9.812 & -5.321 & 4.491 & 2.245 & -7.566 & 12.746 \\
\hline $\begin{array}{l}\text { Salicylidene-p- } \\
\text { hydroxy aniline }\end{array}$ & -9.796 & -4.900 & 4.896 & 2.448 & -7.348 & 11.028 \\
\hline $\begin{array}{l}\text { Salicylidene-o- } \\
\text { hydroxy aniline } \\
\text { (Salt) }\end{array}$ & -9.516 & -5.731 & 3.785 & 1.892 & -7.623 & 15.352 \\
\hline $\begin{array}{l}\text { Salicylidene-m } \\
\text {-hydroxy aniline } \\
\text { (Salt) }\end{array}$ & -9.973 & -5.792 & 4.181 & 2.090 & -7.882 & 14.859 \\
\hline $\begin{array}{l}\text { Salicylidene-p- } \\
\text { hydroxy aniline } \\
\text { (Salt) }\end{array}$ & -9.997 & -5.630 & 4.367 & 2.183 & -7.813 & 13.978 \\
\hline
\end{tabular}


Table (11) : Charges on heteroatoms of acids and their salts.

\begin{tabular}{|l|l|l|l|}
\hline Comp. & O- aldehyde & O- amine & N \\
\hline Salicylidene-o-hydroxy aniline & -0.258 & -0.298 & -0.219 \\
\hline Salicylidene-m-hydroxy aniline & -0.251 & -0.269 & -0.234 \\
\hline \begin{tabular}{c} 
Salicylidene-p- hydroxyl aniline \\
\hline $\begin{array}{c}\text { Salicylide-o-hydroxy aniline } \\
\text { (salt) }\end{array}$
\end{tabular} & -0.255 & -0.259 & -0.216 \\
\hline $\begin{array}{c}\text { Salicylidene-m-hydroxyaniline } \\
\text { (salt) }\end{array}$ & -0.721 & -0.728 & -0.091 \\
\hline $\begin{array}{c}\text { Salicylidene-p- hydroxy aniline } \\
\text { (salt) }\end{array}$ & -0.756 & -0.807 & -0.134 \\
\hline
\end{tabular}

Looking at the values obtained listed in Tables (9-11) we may conclude the followings:

1. The ortho compound (Salicylidene-o-hydroxy aniline ) exhibited higher stretch and bonding energy than the others which may be resulted from the steric interaction induced by the $\mathrm{OH}$ group exist on the ortho position to the imine group.

2. The interaction of the non 1,4 Van der Waals type seemed to be as a stabilizing factor (negative value) in the acid and decreasing in the order:Salicylidene-o-hydroxy aniline >Salicylidene-p- hydroxy aniline $\geq$ Salicylidene-m-hydroxy aniline

and decreasing the stability of the salt molecules in the opposite order:

(Salicylidene-o-hydroxy aniline SSalicylidene-m-hydroxy aniline $<$ Salicylidene-p- hydroxy aniline). This trend of variation could be attributed to the presence of inter and intramolecular hydrogen bonding in the acid molecules, while such bonds are vanished in the salt molecules.

3. Considerable decrease is noticed in the total energies of salt molecules due the rise of another type of interaction known as charge - tocharge interactions resulted from the simple and complete ionization of the salt molecules in the aqueous solution when compared to the ionization of the acidic molecules.

4. The trend of variations in the differences between the energies of the LUMO and HOMO $(\Delta \mathrm{L}-\mathrm{H})$ orbitals and the hardness of the molecules are consistent and vary in the order: Salicylidene-p- hydroxy aniline $>$ Salicylidene-m-hydroxy aniline $>$ Salicylidene-o-hydroxy aniline in both of the acidic and salt molecules, in spite of that, the salts having less values. This give an indication that, the salts are more active than the acidic molecules. 
5. The low values of the $\mu$ and $\omega$ of the acidic forms refer to that, the acidic molecules are more liable to accept electrons, and, therefore, more difficult to be ionized than the salt forms.

6. The relative decrease of the electronic charges on the nitrogen atoms of the imine groups in the salt molecules with respect to the acid forms support the charge distribution over the two rings of the later due to resonance according to the forms suggested and presented in diagram(1). 7. The overall variations discussed so far in the previous points did not give a clear relationship with the ionization constants of the studied compounds. This may indicate that, these parameters are either work together or oppose each other to give a net effect on the Ka values representing anon additive effect of variations (i.e a direct relationship between the Ka values and individual parameter could only be observed).

\section{Reference}

1. H.Keypour, M.Sharifi-Rad ,S. Salehzadeh, H, Khaves and L. Valencia, J.Organometalic Chemistry, 693(2008)3179-3187.

2. J.Liang, G. Steinberg, N.Lirnah, M.Sheves,T.G Ebrey and M.Tsuda, Biophysical Journal, 67(1994)848 - 854 .

3. A.S.P.Azzouz ,Spectroscopy Letters , 2811(1995).

4. A.S.P Azzouzand F.H.M Al Taai , J,Edu Sci.,23(3) (2010) 17-29.

5. A.S.P Azzouz and F.H.M.Al.Taai,J.Edu.Sci., 23(3)(2010) 1-16.

6. A.S.P Azzouz and M.A.Hussin, J.Edu.Sci.,24(3) (2011) 1-15 .

7. J. K.Gupta, Biplab De and V.S.Saravanon, Indian J. Chemistry, 45 B, (2006) 25802582

8. H.N.Aiyu and I.Bello, Biokrmistri , 22(2), (2010)

9. A.I.Vogel ," Text book of practical organic chemistry ", $3^{\text {rd }}$ ed. Longman, London, (1956) 344-345.

10. G.C.Pimental and A.I and A.I McCellan, "The hydrogen bond", Freeman, San Francisco (1960)169-195.

11. S.H.Maron and J.B.Lando,"Fundamental of physical chemistry"MacMillan, New York (1974) 511.

12. M.A.H. Al-Zabaidi, M.Sc.Thesis, Mosul University,2005.

13. A.S.PAzzouz, M.M.H.AL-NiemiandR.T.AL Abadee. J.Edu .Sci.,(2012) In press.

14. K.I.AL-Niemi , Ph,D. Thesis, MosulUniversity, College of Education, 1999

15. K.I.Ramachandran, G.Deepa and K. Namboori, "Computational Chemistry and Molecular Modeling, Principles and Applications" SpringerVerlagBerlinHerdelberg,(2008) 141.

16. A.Vektariene, G.Vectaris and J,Svoboda ,ARKIVOC,(2009) 311-329.

17. G.D.Veith andO.G.Mekenyan,Quant.Struct.Acta.Relat, 12(1993) 349-356. 